\title{
PENGEMBANGAN "DIGITAL INTERACTIVE STORYTELLER” BERBASIS ANDROID UNTUK TUNANETRA
}

\author{
Anak Agung Istri Ita Paramitha ${ }^{1}$, Made Windu Antara Kesiman ${ }^{2}$, I Ketut Resika Arthana ${ }^{3}$ \\ Jurusan Pendidikan Teknik Informatika \\ Universitas Pendidikan Ganesha \\ Singaraja, Bali \\ E-mail: agi.itaparamitha@gmail.com ${ }^{1}$,dekndu@yahoo.com² ${ }^{2}$ resika.arthana@gmail.com³
}

\begin{abstract}
Abstrak- Storytelling merupakan suatu kesenian yang dilakukan secara lisan dengan alat atau tanpa alat untuk menyampaikan sesuatu yang dapat berupa pesan, informasi ataupun cerita yang menghibur. Storytelling memiliki banyak manfaat dalam perkembangan anak, salah satunya adalah mengembangkan imajinasi anak. "Digital Interactive Storyteller" merupakan aplikasi storytelling dengan menggunakan perangkat Android yang ditujukan untuk pengguna tunanetra. Penelitian ini bertujuan untuk merancang dan mengimplementasikan rancangan aplikasi "Digital Interactive Storyteller" Berbasis Android untuk Tunanetra. Pengembangan aplikasi "Digital Interactive Storyteller" Berbasis Android untuk Tunanetra menggunakan siklus hidup pengembangan perangkat lunak SDLC (Software Development Life Cycle) dengan model waterfall atau model air terjun. Fitur utama dalam aplikasi ini adalah audio dongeng interaktif dengan menggunakan perangkat Android. Interaktif yang dimaksudkan adalah pengguna dapat memilih alur dongeng sendiri.

Hasil dari penelitian ini yaitu perancangan dan implementasi dari aplikasi "Digital Interactive Storyteller" Berbasis Android untuk Tunanetra yang telah berhasil dilakukan. Perancangan dilakukan dengan menggunakan model fungsional berupa UML (Unified Modeling Language). Diimplementasikan dalam bahasa pemrograman Java dengan menggunakan editor Eclipse dan plug-ins ADT (Android Development Tools). Seluruh kebutuhan
\end{abstract}

fungsional telah berhasil diimplementasikan sesuai dengan rancangan.

Kata Kunci- Digital Interactive Storyteller, Android

Abstract - Storytelling is an art which can be done either with tools or not to convey message, information or entertaining story. Storytelling has many benefits for child development; one of them is to increase child's imagination. "Digital Interactive Storyteller" is an application using Android devices that intended for blind user. This research aims to design and implement "Digital Interactive Storyteller" an Android-based Application for Blind People.

Development of the Digital Interactive Storyteller" an Android-based Application for Blind People is using the software development life cycle SDLC (Software Development Life Cycle) with the waterfall model. The main feature in this application is an interactive audio story using Android devices. Interactive here means the users can choose their own storyline.

The result of this research is the design and implementation of the Digital Interactive Storyteller" an Android-based Application for Blind People that has been successfully carried out. The design is done by using a functional model of the UML (Unified Modeling Language). Implemented in Java programming language using the Eclipse editor and ADT (Android Development Tools). The entire functional requirements have been successfully implemented in accordance with the design.

Keyword-Digital Interactive Storyteller, Android 


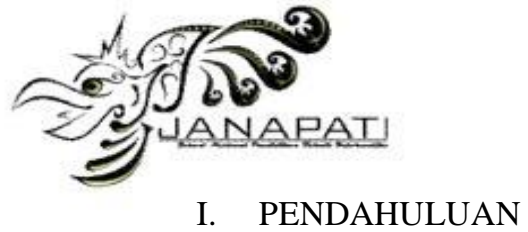

Keluarbiasaan merupakan suatu istilah yang sering kita dengar. Secara harfiah keluarbiasaan berarti menggambarkan sesuatu yang luar biasa. Dilihat dari arah penyimpangannya, jenis keluarbiasaan dapat dibagi menjadi dua kategori, yaitu : keluarbiasaan yang berada di atas normal dan keluarbiasaan yang berada di bawah normal [1]. Salah satu istilah untuk keluarbiasaan di bawah normal yaitu tunanetra. Istilah tunanetra digunakan untuk mereka yang mengalami gangguan penglihatan yang mengakibatkan fungsi penglihatan tidak dapat dilakukan. Banyaknya studi menunjukkan bahwa siswa-siswa tunanetra tidak berbeda dari siswa-siswa yang awas dalam hasil tes intelegensi verbal. Bahkan kebanyakan anak tunanetra lebih termotivasi daripada anak awas untuk menggunakan bahasa karena bahasa merupakan saluran utama komunikasinya dengan orang lain.

Salah satu metode yang dapat digunakan adalah metode bercerita atau dalam bahasa asing disebut dengan storytelling. Pengertian bercerita yaitu suatu kegiatan yang dilakukan seseorang secara lisan kepada orang lain dengan alat atau tanpa alat tentang apa yang harus disampaikan dalam bentuk pesan, informasi atau hanya sebuah dongeng yang untuk didengarkan dengan rasa menyenangkan oleh karena orang yang bercerita tersebut menyajikannya dengan menarik [2]. Di kalangan anak-anak cerita yang paling digemari umumnya berbentuk dongeng karena dongeng dapat membawa anak berfantasi tanpa batas. Beberapa manfaat dongeng yaitu cara efektif menanamkan budi pekerti, sarana mengembangkan imajinasi anak, menumbuhkan minat baca pada anak, meningkatkan kemampuan berbahasa dan komunikasi verbal anak, melatih daya simak anak, meningkatkan kecerdasan, memperoleh pengetahuan baru dan dapat menjaga interaksi emosional dengan anak [3].

Menyadari besarnya manfaat storytelling, kini telah banyak dikembangkan buku dongeng digital baik pada komputer maupun mobile device. Perkembangan teknologi informasi saat ini telah memungkinkan tunanetra mengoperasikan smartphone layar sentuh maupun tablet dengan mudah. Android sendiri telah mengembangkan fasilitas talkback yaitu aplikasi pembaca layar yang memberikan umpan balik yang diucapkan saat melakukan navigasi pada device.

Melihat banyaknya pengguna Android hingga saat ini dan besarnya manfaat storytelling, maka penulis tertarik untuk mengembangkan
ISSN 2089-8673

matika (JANAPATI)

Volume 3, Nomor 3, Desember 2014

aplikasi dengan judul "Pengembangan Aplikasi "Digital Interactive Storyteller" untuk Tunanetra Berbasis Android". Pada aplikasi ini akan disajikan audio dongeng dalam bahasa Inggris. Aplikasi yang dikembangkan akan lebih interaktif dengan pengguna. Interaktif yang dimaksudkan adalah pengguna dapat memilih alur dongeng sendiri. Pemilihan alur pada aplikasi ini berdasarkan jawaban yang diinginkan oleh pengguna. Sehingga nantinya akan terdapat akhir cerita yang berbeda sesuai dengan jawaban pengguna.

\section{KAJIAN TEORI}

\section{A. Tunanetra}

Baraga [1] mengemukakan bahwa orang yang buta memiliki persepsi sinar tanpa proyeksi (yang berarti mereka merasakan adanya sinar tetapi tidak mampu untuk memproyeksikannya atau mengidentifikasi sumber sinar) atau sama sekali tidak memiliki persepsi sinar. Sedangkan ahli lain yaitu De Mott [1] menyatakan bahwa istilah buta diberikan kepada orang yang sama sekali tidak memiliki penglihatan atau yang hanya memiliki persepsi cahaya. Jadi, istilah tunanetra digunakan untuk menggambarkan tingkatan kerusakan atau gangguan penglihatan yang berat yang dikelompokkan secara umum menjadi buta dan kurang lihat. Istilah ini meskipun menggambarkan kekurangan, namun mengandung rasa bahasa yang dapat diterima.

\section{B. Dongeng}

Secara umum dongeng adalah cerita yang dituturkan atau dituliskan yang sifatnya hiburan dan biasanya merupakan cerita yang tidak benar benar terjadi [4]. Tujuan dongeng selain untuk menghibur pendengar juga menanamkan pesan, nasihat yang positif terutama kepada anak-anak tentang moral dan keperibadian. Menurut Aarne dan Stith Thompson [5] jenis-jenis dongeng yaitu : dongeng binatang (animal tales), dongeng biasa (ordinary folktales), lelucon atau anekdote (joke and anecdote) dan dongeng berumus (formula tales).

\section{Storytelling}

Pellowski (1977) mendefinisikan storytelling sebagai sebuah seni atau seni dari sebuah keterampilan bernarasi dari cerita-cerita dalam bentuk syair atau prosa, yang dipertunjukkan atau dipimpin oleh satu orang dihadapan audience secara langsung dimana cerita tersebut dapat dinarasikan dengan cara diceritakan 
ISSN 2089-8673

Jurnal Nasional Pendidikan Teknik Informatika (JANAPATI)

Volume 3, Nomor 3, Desember 2014

atau gambar, ataupun dengan iringan lain yang mungkin dapat dipelajari secara lisan, baik melalui sumber tercetak, ataupun melalui sumber rekaman mekanik [6]. Seni dongeng di Indonesia sebagai tradisi penuturan cerita sudah tumbuh sejak berabad-abad silam [7]. Hidup para pendongeng ini bahkan dijamin oleh raja. Manfaat kegiatan storytelling untuk anak adalah sebagai berikut:

1. mengasah imajinasi anak;

2. mengembangkan kemampuan berbahasa;

3. mengembangkan aspek sosial;

4. mengembangkan aspek moral;

5. mengembangkan aspek spiritual;

6. mengembangkan aspek emosi;

7. menumbuhkan semangat berprestasi;

8. melatih konsentrasi anak [8].

\section{Android}

Android adalah sebuah sistem operasi untuk perangkat mobile berbasis linux yang mencakup sistem operasi, middleware dan aplikasi. Android menyediakan platform terbuka bagi para pengembang untuk menciptakan aplikasi mereka [9]. Android merupakan platform mobile pertama yang lengkap, terbuka dan bebas [9]. Pada Android versi 4.0 fitur talkback ditambahkan untuk meningkatkan aksesibilitas untuk pengguna tunanetra.

\section{METODOLOGI}

Pengembangan "Digital Interactive Storyteller" untuk Tunanetra Berbasis Android ini menggunakan siklus SDLC (System Development Life Cycle). Model waterfall menyediakan pendekatan alur hidup perangkat lunak secara sekuensial atau terurut dimulai dari analisis, desain, pengodean, pengujian, dan tahap pendukung (support) atau pemeliharaan [10].

\section{A. Analisis Masalah dan Usulan Solusi}

Berdasarkan analisis yang peneliti lakukan, terdapat berbagai macam metode untuk menyampaikan pesan pembelajaran bahasa yang dapat merangsang dan menambah kosakata serta dapat mengasah imajinasi anak. Salah satu metode yang dapat digunakan adalah metode bercerita atau dalam bahasa asing disebut dengan storytelling. Cerita yang digemari anak-anak pada umumnya berbentuk dongeng. Dengan mendengarkan dongeng dapat mengembangkan imajinasi anak, meningkatkan kemampuan berbahasa dan komunikasi verbal anak, melatih daya simak anak, meningkatkan kecerdasan, memperoleh pengetahuan baru dan dapat menjaga interaksi emosional dengan anak. Menyadari besarnya manfaat storytelling, kini telah banyak dikembangkan buku dongeng digital baik pada komputer maupun mobile device. Namun, aplikasi dongeng yang dapat digunakan untuk tunanetra tidaklah sebanyak aplikasi untuk anak awas.

Jadi solusi yang peneliti usulkan berdasarkan permasalahan di atas adalah dengan mengembangkan sebuah aplikasi "Digital Interactive Storyteller" untuk Tunanetra Berbasis Android". Pada aplikasi ini akan disajikan audio dongeng dalam bahasa Inggris. Aplikasi yang dikembangkan akan lebih interaktif dengan pengguna. Interaktif yang dimaksudkan adalah pengguna dapat memilih alur dongeng sendiri. Pemilihan alur pada aplikasi ini berdasarkan jawaban yang diinginkan oleh pengguna. Sehingga nantinya akan terdapat akhir cerita yang berbeda sesuai dengan jawaban pengguna.

B. Analisis Perangkat Lunak

1. Kebutuhan Perangkat Lunak

Aplikasi Digital Interactive Storyteller Berbasis Android dirancang agar dapat mengimplementasikan kebutuhan fungsional sebagai berikut.

a. Menampilkan Menu Utama yang terdiri dari Introduction dan About.

b. Memutar audio dongeng.

c. Memberikan pilihan alur dongeng.

d. Melakukan pembaharuan basis data.

e. Mengunduh audio dongeng yang diperlukan.

f. Menampilkan tentang pengembang aplikasi.

Adapun kebutuhan non-fungsional dari aplikasi yang dikembangkan adalah sebagai berikut.

a. Desain aplikasi "Digital Interactive Storyteller" untuk Tunanetra Berbasis Android dirancang untuk memudahkan pengguna tunanetra menggunakannya (user friendly).

b. Audio dongeng dapat didengar dengan jelas.

c. Aplikasi yang dikembangkan minimal dapat berjalan pada sistem operasi Android versi 4.0.

2. Tujuan Pengembangan Perangkat Lunak

Adapun tujuan pengembangan perangkat lunak adalah sebagai berikut.

a. Aplikasi dapat menampilkan Menu Utama yang terdiri dari Introduction dan About.

b. Aplikasi dapat memutar audio dongeng. 
ISSN 2089-8673

Jurnal Nasional Pendidikan Teknik Informatika (JANAPATI)

Volume 3, Nomor 3, Desember 2014

Aplikasi dapat memberikan pilihan alur dongeng.

d. Aplikasi dapat melakukan pembaharuan basis data.

e. Aplikasi dapat mengunduh audio dongeng yang diperlukan.

f. Aplikasi dapat menampilkan tentang pengembang.

3. Masukan dan Keluaran Perangkat Lunak

Masukan (input) pada Aplikasi Digital Interactive Storyteller Berbasis Android untuk Tunanetra adalah berupa sentuhan (touch) pada layar, sedangkan keluaran (output) dari aplikasi adalah audio dongeng dan pilihan alur dongeng.

\section{Model Fungsional Perangkat Lunak}

Dalam pengembangan aplikasi ini, peneliti menggunakan use-case diagram, activity diagram dan sequence diagram.

\section{a. Use Case Diagram}

Use case atau diagram use case merupakan pemodelan untuk kelakuan (behavior) sistem informasi yang akan dibuat. Use case mendeskripsikan sebuah interaksi antara satu atau lebih aktor dengan sistem informasi yang akan dibuat.

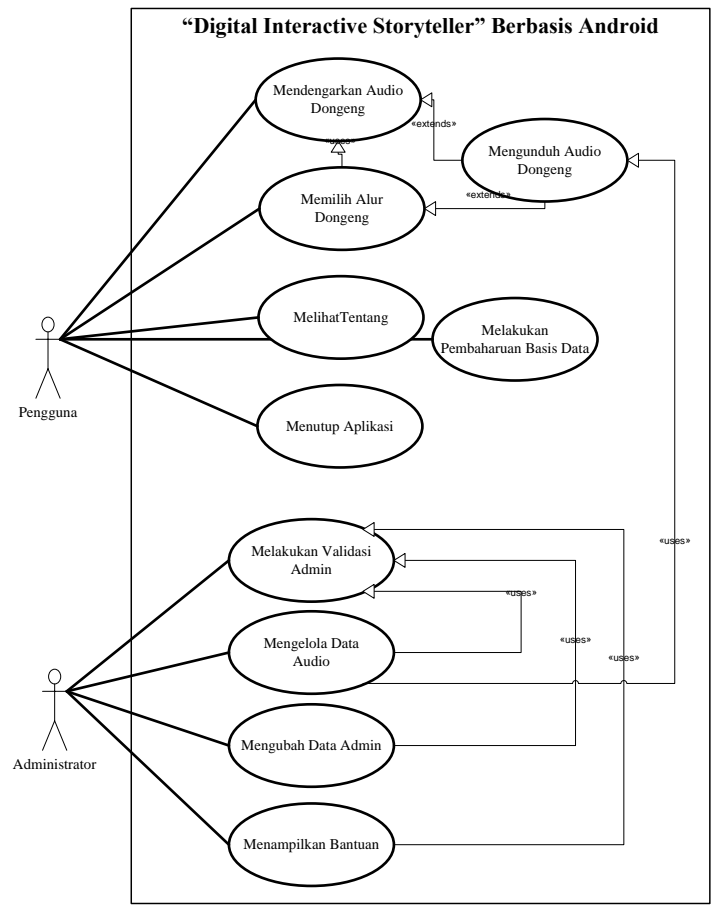

Gambar 1. Use Case Diagram

\section{b. Activity Diagram}

Activity diagram menggambarkan berbagai alir aktivitas dalam sistem yang sedang dirancang, bagaimana masing-masing alir berawal, decision yang mungkin terjadi, dan bagaimana mereka berakhir. Activity diagram juga dapat menggambarkan proses paralel yang mungkin terjadi pada beberapa eksekusi.
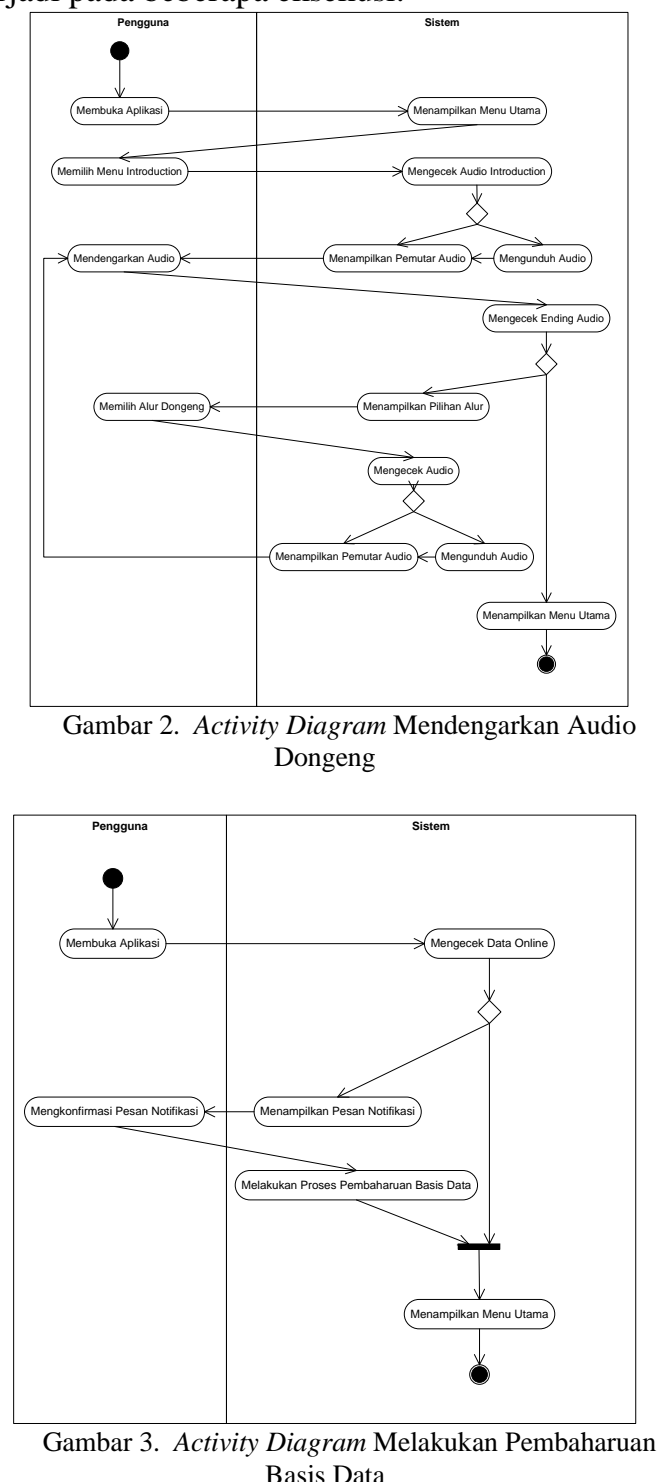

c. Sequence Diagram

Sequence diagram menggambarkan kelakuan objek pada use case dengan mendeskripsikan waktu hidup objek dan message yang dikirimkan dan diterima antar objek. 


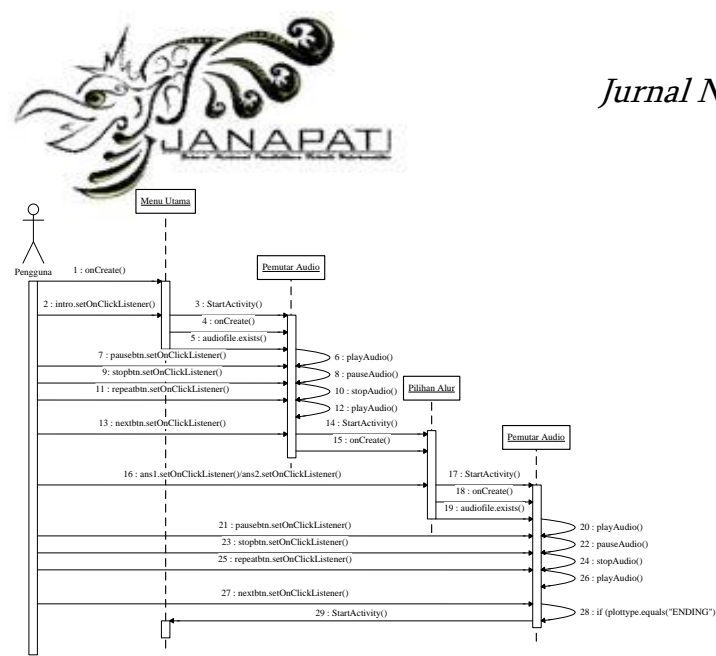

Gambar 4. Sequence Diagram Mendengarkan Audio Dongeng

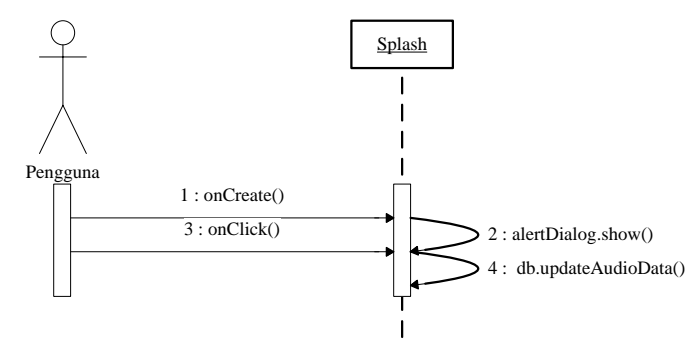

Gambar 5. Sequence Diagram Melakukan Pembaharuan Basis Data

C. Perancangan Perangkat Lunak

1. Batasan Perancangan Perangkat Lunak

Adapun batasan perancangan dalam pengembangan aplikasi ini yaitu: (1) Audio dongeng menggunakan bahasa Inggris; (2) Aplikasi ini berjalan dengan optimal pada sistem operasi Android yang telah memiliki fasilitas talkback.

\section{Perancangan Arsitektur Perangkat Lunak}

Perancangan arsitektur perangkat lunak adalah perancangan modul-modul yang akan dikembangkan dalam aplikasi "Digital Interactive Storyteller" Berbasis Android untuk Tunanetra. Gambar 6 merupakan rancangan arsitektur perangkat lunak yang akan dibangun.
ISSN 2089-8673

Volume 3, Nomor 3, Desember 2014

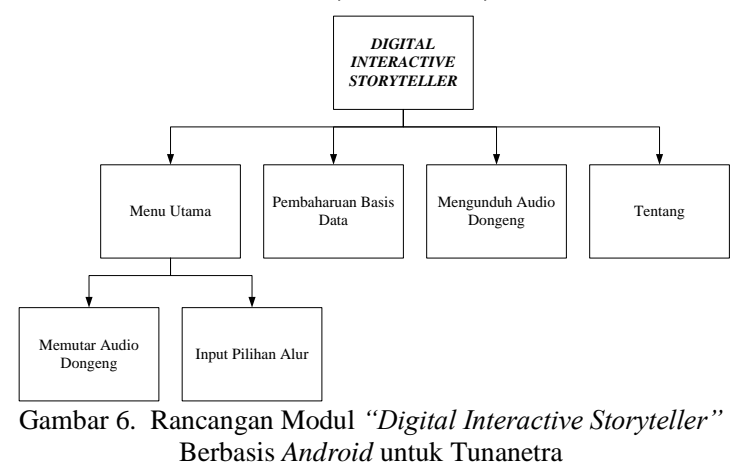

\section{Perancangan Struktur Menu}

Struktur menu merupakan struktur atau alur dari suatu program. Perancangan struktur menu perangkat lunak ini terdiri dari beberapa komponen. Berikut ini merupakan rancangan struktur menu perangkat lunak yang akan dibangun pada aplikasi "Digital Interactive Storyteller" Berbasis Android untuk Tunanetra.

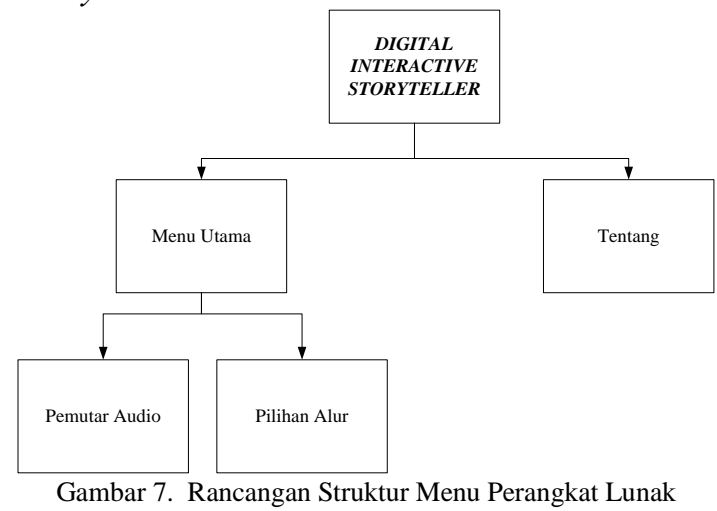

4. Perancangan Antarmuka Perangkat Lunak Perancangan antarmuka perangkat lunak pengguna merupakan proses pembuatan antarmuka yang akan digunakan untuk interaksi antara pengguna dengan perangkat lunak Android.

a. Rancangan Antarmuka Splash

Loading...

Gambar 8. Rancangan Antarmuka Splash

b. Rancangan Antarmuka Menu Utama 
ISSN 2089-8673

Jurnal Nasional Pendidikan Teknik Informatika (JANAPATI)

Volume 3, Nomor 3, Desember 2014

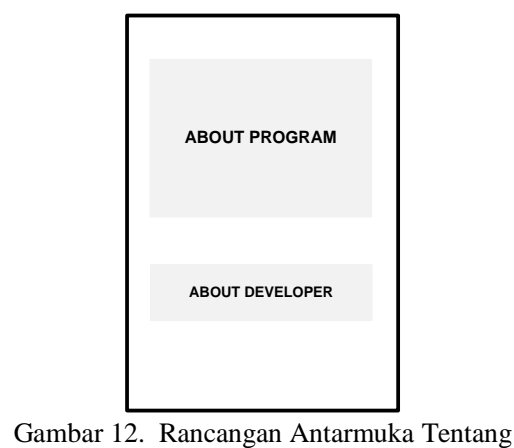

\section{IV.PEMBAHASAN}

c. Rancangan Antarmuka Pemutar Audio

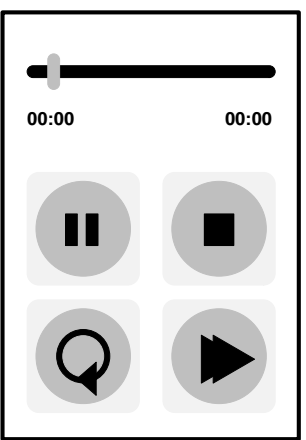

Gambar 10. Rancangan Antarmuka Pemutar Audio

d. Rancangan Antarmuka Pilihan Alur

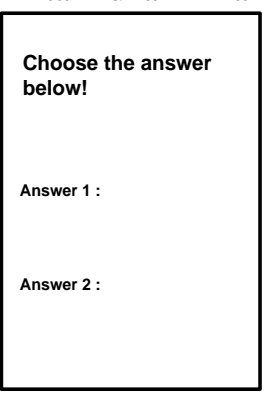

Gambar 11. Rancangan Antarmuka Pilihan Alu

e. Rancangan Antarmuka Tentang

A. Implementasi Perangkat Lunak

1. Lingkungan Implementasi Perangkat Lunak Implementasi Aplikasi Digital Interactive Storyteller Berbasis Android untuk Tunanetra dilakukan pada lingkungan perangkat lunak dan perangkat keras sebagai berikut.

a. Perangkat Lunak

(1) Eclipse Version: 4.2.1

(2) Plugins ADT (Android Development Tools) Version: 22.0.5

(3) Corel Draw X4

(4) Audacity 2.0.5

(5) Notepad ++

(6) ХАMPP 1.7.4

(7) phpMyAdmin 3.3.9

b. Perangkat Keras

(1) Laptop dengan spesifikasi sebagai berikut.

a) Monitor 14,1 inchi dengan resolusi 1366 x 768

b) Memori 2 GB RAM dan harddisk $320 \mathrm{~GB}$

c) Prosesor Intel $\AA$ Core ${ }^{\mathrm{TM}}$ i3 2.27 Ghz

(2) Perangkat Android dengan spesifikasi sebagai berikut.

a) Android 4.3 (Jelly Bean)

b) CPU Dual-core $1.7 \mathrm{GHz}$.

c) GPU Adreno 320

d) Display dengan resolusi $720 \mathrm{x}$ 1280

2. Batasan Implementasi Perangkat Lunak

a. Spesifikasi perangkat Android minimal yang diperlukan untuk menjalankan aplikasi adalah sebagai berikut:

(1) memiliki fasilitas talkback.

(2) RAM 512 MB.

$b$. Audio dongeng dalam aplikasi ini menggunakan bahasa Inggris. 
ISSN 2089-8673

Jurnal Nasional Pendidikan Teknik Informatika (JANAPATI)

Volume 3, Nomor 3, Desember 2014

Audio yang ada pada aplikasi ini harus diunduh terlebih dahulu sebelum bisa diputar.

3. Implementasi Antarmuka Perangkat Lunak

Implementasi antarmuka dilakukan sesuai dengan rancangan antarmuka yang telah dibuat sebelumnya.

a. Implementasi Antarmuka Splash

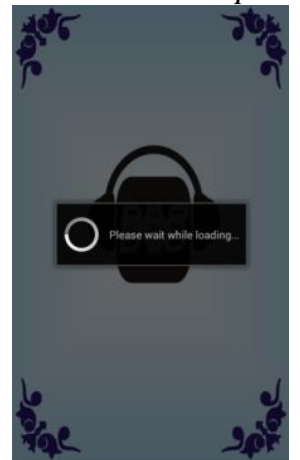

Gambar 13. Implementasi Antarmuka Menu Utama

b. Implemenasi Antarmuka Menu Utama

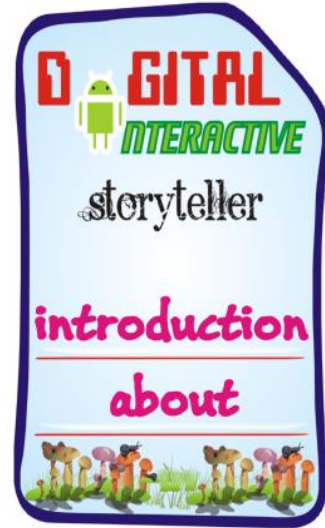

Gambar 14. Implementasi Antarmuka Menu Utama

c. Implemenasi Antarmuka Pemutar Audio

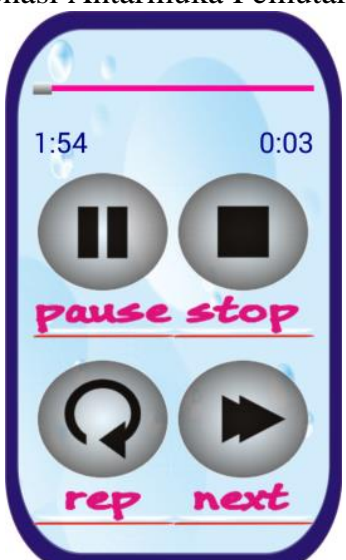

Gambar 15. Implementasi Antarmuka Pemutar Audio

d. Implemenasi Antarmuka Pilihan Alur

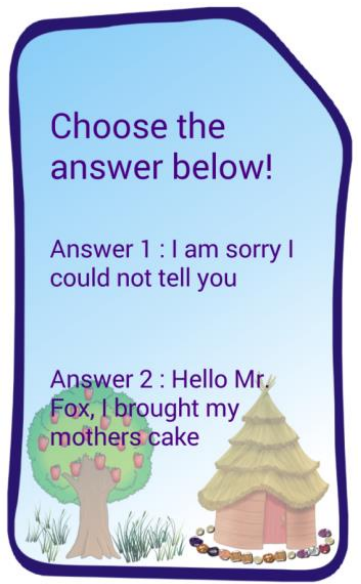

Gambar 16. Implementasi Antarmuka Pilihan Alur

e. Implemenasi Antarmuka Tentang

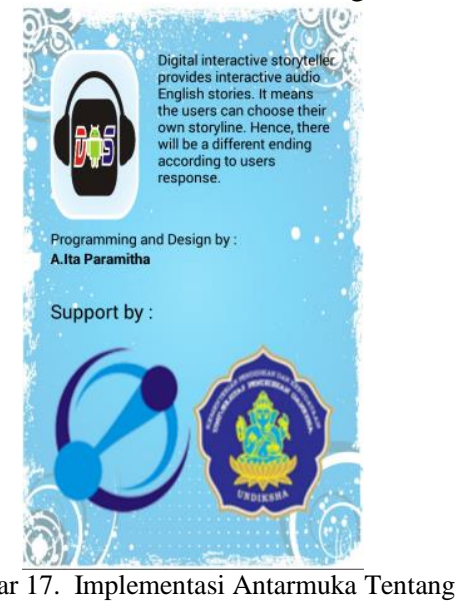

Gambar 17. Implementasi Antarmuka Tentang

B. Pengujian Perangkat Lunak

1. Tujuan Pengujian Perangkat Lunak

Tujuan pengujian aplikasi "Digital Interactive Storyteller" Berbasis Android untuk Tunanetra, yaitu:

a. Menguji penggunaan aplikasi "Digital Interactive Storyteller" Berbasis Android untuk Tunanetra pada perangkat Android yang berbeda.

b. Menguji kebenaran proses aplikasi "Digital Interactive Storyteller" Berbasis Android untuk Tunanetra.

c. Menguji kualitas suara audio dongeng.

2. Perancangan Kasus Uji Pengujian Perangkat Lunak

Pada tahap ini dideskripsikan secara mendetail bentuk uji kasus yang akan dilaksanakan dan telah disesuaikan dengan tujuan pengujian dan tata ancang pengujian yang telah 
ISSN 2089-8673

Jurnal Nasional Pendidikan Teknik Informatika (JANAPATI)

Volume 3, Nomor 3, Desember 2014

diteta $n$. Uji kasus dibuat selengkap mungkin agar hasil pengujian sesuai dengan keadaan sistem sebenarnya.Terdapat tiga kasus uji yang dirancang sesuai dengan tujuan pengujian perangkat lunak yang digambarkan dengan angket pengujian.

3. Pelaksanaan Pengujian Perangkat Lunak Pengujian perangkat lunak "Digital Interactive Storyteller" Berbasis Android untuk Tunanetra dilakukan oleh tujuh orang yang berbeda dan menggunakan beberapa perangkat Android dengan merk dan spesifikasi yang berbeda. Pengujian dilaksanakan pada hari Jumat, 27 Juni 2014 dengan penguji yaitu anak - anak Panti Sosial Bina Netra Mahatmiya, Kediri, Tabanan.

4. Evaluasi Hasil Pengujian Perangkat Lunak Aplikasi "Digital Interactive Storyteller" Berbasis Android untuk Tunanetra dapat dijalankan pada semua perangkat Android yang diujikan sesuai dengan kebutuhan minimum aplikasi yang telah ditetapkan. Pengujian dilakukan dengan menggunakan perangkat Android dengan merk diantaranya Samsung, Sony Xperia, dan Advan dengan spesifikasi yang berbeda-beda. Seluruh fitur yang terdapat pada aplikasi "Digital Interactive Storyteller" Berbasis Android untuk Tunanetra dapat dijalankan dan tidak terjadi error. Untuk kualitas audio dongeng lima orang dari penguji memberikan penilaian baik dan 2 orang penguji memberikan penilaian sedang.

\section{SIMPULAN}

Berdasarkan penelitian dan pengembangan aplikasi "Digital Interactive Storyteller" Berbasis Android untuk Tunanetra yang telah dilakukan, maka diperoleh kesimpulan sebagai berikut.

a. "Digital Interactive Storyteller" Berbasis Android untuk Tunanetra merupakan aplikasi audio dongeng interaktif dalam bahasa Inggris.

b. Perancangan "Digital Interactive Storyteller" Berbasis Android untuk Tunanetra telah berhasil dilakukan dengan menggunakan model fungsional berupa UML (Unified Modeling Languange) yaitu dengan menggunakan use case diagram, activity diagram, dan sequencediagram.

c. Aplikasi "Digital Interactive Storyteller" Berbasis Android untuk Tunanetra telah berhasil diimplementasikan sesuai dengan rancangan yang telah dibuat sebelumnya. "Digital Interactive Storyteller" Berbasis Android untuk Tunanetra diimplementasikan menggunakan bahasa pemrograman Java dengan editor Eclipse versi 4.2.1 dan plug-ins ADT (Android Development Tools) versi 22.0.5.

d. Fitur utama dari aplikasi "Digital Interactive Storyteller" Berbasis Android untuk Tunanetra adalah mendengarkan audio dongeng, memilih alur dongeng, serta melakukan pembaharuan basis data.

e. Aplikasi "Digital Interactive Storyteller" Berbasis Android untuk Tunanetra dapat berjalan pada perangkat Android yang sesuai dengan spesifikasi minimal yang telah ditetapkan sebelumnya.

\section{REFERENSI}

[1]. Wardani, I.G.A.K et.al.2007.Pengantar Pendidikan Luar Biasa.Jakarta: Universitas Terbuka.

[2]. Dhieni, N.2005.Metode Pengembangan Bahasa.Pusat Penerbitan Universitas Terbuka Tangerang.

[3]. Kemdikbud.2012.Juli.“Dongeng Bentuk Karakter Anak”.Warta Paudni.Hlm.7-10.

[4]. Kamisa.1997.Kamus Lengkap Bahasa Indonesia.Surabaya: Kartika.

[5]. Danandjaja, James.2002.Folklor IndonesiaIlmu Gosip, Dongeng, dan Lain-lain.Jakarta: Grafiti.

[6]. Boltman, Angela.2001.“Children's Storytelling Technologies: Differences in Ellaboration and Recall”. http://itiseer.1st.psu.edo/563253.html (diakses tanggal 28 Desember 2013).

[7]. Asfandiyar, \& Yudha A.2007.Cara Pintar Mendongeng.Jakarta: Mizan.

[8]. Musfiroh, Tadkiroatun. et al.2005.Cerita dan Perkembangan Anak. Yogyakarta: Novila.

[9]. Safaat H, Nazruddin.2012.Android.Bandung: Informatika.

[10]. S, Rosa A. dan M. Shalahuddin.2013. Rekayasa Perangkat Lunak.Bandung: Informatika. 